\title{
DISKRESI KEPOLISIAN DALAM PENANGANAN TINDAK PIDANA KECELAKAAN LALU LINTAS DENGAN KORBAN PEJALAN KAKI (Studi di Polres Purbalingga) \\ Oleh: R. Manggala Agung $\mathrm{SM}^{13}$
}

\begin{abstract}
Discretion refers to a Police authority of police officials to act or not to act legally in carrying out its work. Diskresi allows a police officer to choose among a variety of roles (maintain order, enforce the law or protect society), tactics (enforce traffic laws by on patrol or manning at one place) or the destination ( punish violators or advice) in the execution of his duty.

This research approach is the juridical sociological research, specification descriptive in nature, as well as analyze qualitative methods. The goal of research to figure out the implementation of the discretion police force in handling the crime of traffic accidents with casualties of iscretion in the area of law Polres Purbalingga.

Against truth and validity it does the action the police discretion, that discretion police formally regulated in article 18 of Act No. 2 of 2002 Year State police of the Republic of Indonesia, which mention that: (1) For general interest, officials of the State police of the Republic of Indonesia in carrying out the tasks and authority can act according to hisown judgment. The implementation of the provisions referred to in subsection (1) may only be carried out in a State that is very necessary having regard to the legislation, as well as the code of conduct of the profession of police of the Republic of Indonesia.
\end{abstract}

Keywords: discretion, police, victim

\section{ABSTRAK}

Diskresi Polisi diartikan sebagai wewenang Pejabat Polisi untuk bertindak atau tidak bertindak secara legal dalam menjalankan tugasnya. Diskresi membolehkan seorang Polisi untuk memilih diantara berbagai peran (memelihara ketertiban, menegakkan hukum atau melindungi masyarakat), taktik (menegakkan undang-undang lalu lintas dengan berpatroli atau berjaga pada suatu tempat) ataupun tujuan (menilang pelanggar atau menasehatinya) dalam pelaksanaan tugasnya.

Pendekatan penelitian ini adalah yuridis sosiologis, spesifikasi penelitian yang bersifat deskriptif, serta menganalisis dengan metode kualitatif. Tujuan penelitian untuk mengetahui pelaksanaan diskresi Kepolisian dalam penanganan tindak pidana kecelakaan lalu lintas dengan korban pejalan kaki di daerah hukum Polres Purbalingga.

Terhadap kebenaran dan keabsahan dilakukannya tindakan diskresi polisi tersebut, Pudi Rahardi mengemukakan bahwa diskresi polisi secara formal diatur dalam Pasal 18 Undang-Undang No. 2 Tahun 2002 tentang Kepolisian Negara Republik Indonesia, yang menyebutkan bahwa: (1) Untuk kepentingan umum, pejabat Kepolisian Negara Republik Indonesia dalam melaksanakan tugas dan wewenangnya dapat bertindak menurut penilaiannya sendiri. Pelaksanaan ketentuan sebagaimana dimaksud dalam ayat (1) hanya dapat dilakukan dalam keadaan yang sangat perlu dengan memperhatikan peraturan perundang-undangan, serta Kode Etik Profesi Kepolisian Negara Republik Indonesia.

Kata Kunci: diskresi, polisi, korban

${ }^{13}$ Pegawai Kepolisian Republik Indonesia Purbalingga, 082227476984/0281891112 
1001 | Jurna | | dea H u kum

VoI. 4 No.2 Oktober 2018

Magister Hukum Fakultas Hukum

Universitas Jenderal Soedirman

\section{A. Pendahuluan}

Diskresi Kepolisian pada dasarnya merupakan kewenangan Kepolisian yang bersumber pada asas Kewajiban umum Kepolisian (Plichtmatigheids beginsel) yaitu suatu asas yang memberikan kewenangan kepada pejabat kepolisian untuk bertindak atau tidak bertindak menurut penilaiannya sendiri, dalam rangka kewajiban umumnya menjaga, memelihara ketertiban dan menjamin keamanan umum. Diskresi Kepolisian di Indonesia secara yuridis diatur pada Pasal 18 Undang-Undang Nomor: 2 Tahun 2002 tentang Kepolisian Negara Republik Indonesia yaitu "Untuk kepentingan umum, pejabat Kepolisian Negara Republik Indonesia dalam melaksanakan tugas dan wewenangnya dapat bertindak menurut penilaiannya sendiri ", hal tersebut mengandung maksud bahwa seorang anggota Polri yang melaksanakan tugasnnya di tengah-tengah masyarakat seorang diri, harus mampu mengambil keputusaan berdasarkan penilaiannya sendiri apabila terjadi gangguan terhadap ketertiban dan keamanan umum atau bila timbul bahaya bagi ketertiban dan keamanan umum.

Diskresi Polisi dapat pula diartikan sebagai wewenang Pejabat Polisi untuk memilih bertindak atau tidak bertindak secara legal atau ilegal dalam menjalankan tugasnya. Diskresi membolehkan seorang Polisi untuk memilih diantara berbagai peran (memelihara ketertiban, menegakkan hukum atau melindungi masyarakat) taktik (menegakkan Undang-Undang Lalu Lintas dengan berpatroli atau berjaga pada suatu tempat) ataupun tujuan (menilang pelanggar atau menasehatinya) dalam pelaksanaan tugasnya. ${ }^{14}$

Kecelakaan lalu-lintas adalah suatu peristiwa di jalan yang tidak disangka-sangka dan tidak di sengaja melibatkan kendaraan dengan atau tanpa pemakai jalan lainnya, mengakibatkan korban manusia atau kerugian harta benda. Secara normatif kecelakaan lalulintas tidak dapat dihindari mengingat kejadian tersebut bukan faktor yang di sengaja oleh pengemudi atau pengguna jalan, tetapi lebih sebagai musibah yang harus di eliminir faktor-faktor yang mengarah pada kejadian tersebut. ${ }^{15}$

\footnotetext{
$14 \quad$ Dikutip dari: https://krisnaptik.com/polri4/hukum-kepolisian/diskresikepolisian-ii/ diakses tanggal 3 Mei 2017, jam 18.51wib

15 Edward K Morlok, 1995 Introduction to Transportation Engenering and Planning, (Pengantar Teknik dan Perencanaan Transportasi), Diterjemahkan oleh Johan Kalanaputra Hainim, Erlangga, Jakarta. hlm. 9
} 


\begin{abstract}
Banyaknya terjadi
kecelakaan lalu-lintas yang menyebabkan korban mengalami luka-luka bahkan meninggal dunia menjadi permasalahan serius dalam rangka menciptakan keteraturan dan ketertiban di jalan raya. Secara umum dapat dikatakan pula bahwa suatu kasus kecelakaan lalu-lintas terjadi akibat kumulatif beberapa faktor penyebab, penyebab tersebut antara lain akibat kelalaian pengemudi, kondisi kendaraan, faktor cuaca, faktor lingkungan jalan dan perubahan fisik pada struktur jalan (umur teknis). Secara empiris pertumbuhan volume arus lalu lintas memiliki korelasi positif dengan jumlah kecelakaan yang terjadi, sehingga jumlah kecelakaanpun walau selalu diupayakan dikurangi, masih ada saja kecelakan yang terjadi. ${ }^{16}$
\end{abstract}

\section{Dalam Undang-Undang}

Nomor 22 Tahun 2009 tentang Lalu Lintas dan Angkutan Jalan, Pasal 1 angka 24 disebutkan bahwa yang dimaksud dengan "kecelakaan lalu lintas adalah suatu peristiwa di jalan yang tidak diduga dan tidak disengaja melibatkan Kendaraan dengan atau tanpa Pengguna Jalan lain yang mengakibatkan korban

16 Besar Setyabudi, 2004. Kajian Peningkatan Keselamatan Lalu Lintas pada Lokasi Rawan Kecelakaan (Blackspot) di Jalan Tol. Warta Penelitian Perhubungan No. 05/Thn.XVI/2004. hlm. 4 manusia dan/atau kerugian harta benda". Selanjutnya dalam Pasal 1 angka 26 disebutkan bahwa yang dimaksud dengan "Pejalan Kaki adalah setiap orang yang berjalan di Ruang Lalu Lintas Jalan".

Kecelakaan lalu lintas sebagai perbuatan yang dapat dipidana, dalam Undang-undang No. 22 Tahun 2009 tentang tentang Lalu Lintas dan Angkutan Jalan, mengatur sanksi pidana penjara dan/ atau denda atas kecelakaan lalu lintas, dalam Penjelasan Umum Undang-undang tentang Lalu Lintas dan Angkutan Jalan disebutkan bahwa pengaturan dan penerapan sanksi pidana diatur lebih tegas. Bagi pelanggaran yang sifatnya ringan, dikenakan sanksi pidana kurungan atau denda yang relatif lebih ringan. Namun, terhadap pelanggaran berat dan terdapat unsur kesengajaan dikenakan sanksi pidana yang jauh lebih berat. Hal ini dimaksudkan agar dapat menimbulkan efek jera bagi pelaku pelanggaran dengan tidak terlalu membebani masyarakat.

Sehubungan dengan penanganan tindak pidana kecelakaan lalu lintas di wilayah hukum Polres Purbalingga, maka sebagai data awal dalam tulisan ini, penulis menyampaikan tentang data jumlah korban Laka Lantas yang melibatkan pejalan kaki di Polres Purbalingga tahun 2014, 2015, dan 2016, data jumlah korban kecelakan 
1003 | Jurna I I dea Hukum

VoI. 4 No.2 Oktober 2018

Magister Hukum Fakultas Hukum

Universitas Jenderal Soedirman

Ialu lintas dimaksud dapat dilihat

dalam tabel sebagai berikut :

Tabel 1: Data Laka Lantas yang melibatkan pejalan kaki 2014 s/d 2016 di Polres Purbalingga

\begin{tabular}{|c|c|c|c|c|c|}
\hline $\begin{array}{c}\mathrm{N} \\
0\end{array}$ & Tahun & $\begin{array}{c}\text { Jumla } \\
\mathrm{h} \\
\text { kecel } \\
\text { akaan }\end{array}$ & $\begin{array}{c}\text { Korban } \\
\text { Mening } \\
\text { gal } \\
\text { Dunia }\end{array}$ & $\begin{array}{c}\text { Korban } \\
\text { Luka } \\
\text { Berat }\end{array}$ & $\begin{array}{c}\text { Korban } \\
\text { Luka } \\
\text { Ringan }\end{array}$ \\
\hline 1 & 2014 & 90 & 38 & 0 & 90 \\
\hline 2 & 2015 & 126 & 37 & 0 & 138 \\
\hline 3 & 2016 & 155 & 38 & 0 & 176 \\
\hline
\end{tabular}

Sumber: Satlantas Polres Purbalingga Memperhatikan tebel tersebut di atas, dapat diketahui bahwa kecelakaan lalu lintas yang berakibat korban mati, luka berat dan luka ringan, ternyata frekuensi kecelakaan lalu lintas yang melibatkan pejalan kaki di wilayah hukum Polres Purbalingga setiap tahun jumlah kecelakaan terus meningkat.

Berdasarkan uraian tersebut di atas, penulis tertarik untuk melakukan penelitian dalam bentuk tesis dengan judul: Diskresi Kepolisian Dalam Penanganan Tindak Pidana Kecelakaan Lalu Lintas Dengan Korban Pejalan Kaki (Studi di Polres Purbalingga)

\section{B. Perumusan Masalah}

1. Bagaimana pelaksanaan diskresi Kepolisian dalam penanganan tindak pidana kecelakaan lalu lintas dengan korban pejalan kaki di daerah hukum Polres

Purbalingga?

2. Dalam hal apakah diskresi Kepolisian dimaksud Pasal 18 Undang-undang No. 2 Tahun 2002 diperlukan?

\section{Perumusan Masalah}

1. Bagaimana pelaksanaan diskresi Kepolisian dalam penanganan tindak pidana kecelakaan lalu lintas dengan korban pejalan kaki di daerah hukum Polres Purbalingga?

2. Dalam hal apakah diskresi Kepolisian dimaksud Pasal 18 Undang-undang No. 2 Tahun 2002 diperlukan?

\section{Metode Penelitian}

Pendekatan yuridis sosiologis atau suatu pedekatan yang menekankan pada suatu pencarianpencarian empirik atau empirical regulation karena mengkonstruksikan hukum sebagai refleksi masyarakat. Dalam penelitian ini penulis mengkaji tentang pelaksanaan diskresi Kepolisian dalam penanganan tindak pidana kecelakaan lalu lintas dengan korban pejalan kaki di daerah hukum Polres Purbalingga. Tipe penelitian ini menggunakan spesifikasi penelitian yang bersifat deskriptif, yaitu menggambarkan tentang fenomena yang ada dilakukan sesuai dengan metode penelitian. Fakta-fakta yang ada digambarkan dengan suatu interpretasi, evaluasi dan pengetahuan umum, karena fakta tidak akan mempunyai arti 
tanpa interpretasi, evaluasi dan pengetahuan umum. ${ }^{17}$

Sumber data primer yaitu data yang diperoleh langsung dari responden yang meliputi: Petugas Penyidik Polres Purbalingga, para pelaku dan korban kecelakaan lalu lintas. Menurut Sumadi Suryabrata, yang dimaksud dengan data sekunder yaitu data yang diperoleh dari bahan kepustakaan data tersebut biasanya telah tersusun dalam bentuk dokumen-dokumen. ${ }^{18}$ Sumber data menurut pendapat yang dikemukakan oleh Soerjono Soekanto dan Sri Mamudji data sekunder terdiri dari bahan hukum primer, bahan hukum sekunder dan bahan hukum tersier. ${ }^{19}$

Analisa data dilakukan dengan menjabarkan dan menganalisis dengan metode kualitatif yaitu menginterpretasikan dan menjabarkan data berdasarkan teori-teori hukum, peraturan-peraturan hukum dan kejadian atau kasus-kasus dalam praktik yang berkaitan dengan pokok permasalahan.

\section{E. Hasil Penelitian dan Pembahasan}

\section{Pelaksanaan diskresi}

Kepolisian dalam penanganan tindak pidana kecelakaan lalu lintas dengan korban pejalan

\footnotetext{
17 I.S. Susanto, 1990. Kriminologi. Fakultas Hukum Universitas Diponegoro, Semarang, hlm. 15

Sumadi Suryabrata, 1992. Metode Penelitian. Rajawali Press, Jakarta, hlm. 84

19 Soerjono Soekanto dan Sri Mamudji, 2007. Op.cit. hlm. 74
}

\section{kaki di daerah hukum Polres Purbalingga}

Sebelum membahas pelaksanaan diskresi kepolisian dalam penanganan tindak pidana kecelakaan lalu lintas dengan korban pejalan kaki, maka terlebih dahulu perlu dijelaskan pengertian diskresi. Diskresi yang berasal dari kata discretion secara umum berarti kebijaksanaan atau keleluasaan, menurut JCT Simorangkir, diskresi diartikan sebagai kebebasan mengambil keputusan dalam setiap situasi yang dihadapi menurut pendapatnya sendiri. ${ }^{20}$

Dalam Undang-Undang No. 22 Tahun 2009 tentang Lalu lintas dan Angkutan Jalan, disebutkan dalam Pasal 1 butir 1 , bahwa yang dimaksud dengan "Lalu lintas adalah gerak kendaraan dan orang di ruang lalu lintas jalan". Pasal 1 butir 7 , bahwa yang dimaksud dengan "Kendaraan adalah suatu sarana angkut di jalan yang terdiri atas kendaraan tidak bermotor dan kendaraan bermotor". Pasal 1 butir 26 yang dimaksud dengan "Pejalan kaki adalah setiap orang yang berjalan di ruang lalu lintas".

20 JCT Simorangkir dkk, 1980. Kamus Hukum, Aksara Baru, hlm. 45 
1005 | Jurna I I d e a H u kum

Vol. 4 No. 2 Oktober 2018

Magister Hukum Fakultas Hukum

Universitas Jenderal Soedirman

Dikemukakan oleh Besar

Setyabudi, ${ }^{21}$ bahwa kecelakaan

lalu-lintas adalah :

"Suatu peristiwa di jalan yang tidak disangka-sangka dan tidak disengaja melibatkan kendaraan dengan atau tanpa pemakai jalan lainnya, mengakibatkan korban manusia atau kerugian harta benda. Secara normatif kecelakaan lalu-lintas tidak dapat dihindari mengingat kejadian tersebut bukan faktor yang disengaja oleh pengemudi atau pengguna jalan, tetapi lebih sebagai musibah yang harus dieliminir faktor-faktor yang mengarah pada kejadian tersebut".

Oleh karena diskresi bergerak di antara berbagai keputusan dan/atau tindakan tersebut, menurut pandangan positivisme hukum diskresi dikatakan beroperasi di antara hukum dan norma, (atau moral). Sehubungan dengan hal ini Thomas J. Aaron merangkum diskresi Polisi sebagai : "Suatu wewenang bertindak yang diberikan kepada Polisi, untuk mengambil keputusan dalam situasi tertentu, yang membutuhkan pertimbangan tersendiri dan menyangkut masalah moral, serta terletak dalam garis antara hukum dan moral". 22

\footnotetext{
cit. hlm. 9

21 Besar Setyabudi, 2004. Op.

${ }^{22}$ Ibid., hlm. 19
}

Dijelaskan oleh penyidik

Laka Lantas Porles Purbalingga dalam menerapkan diskresi terhadap kasus laka lantas sebagai berikut:

"Dengan mengumpulkan anggota untuk melaksanakan gelar perkara tentang kasus kecelakaan yang terjadi, kemudian mempertimbangkan berbagai aspek baik aspek yuridis, filosofis, maupun sosiologis, dan fakta yang ada di lapangan, kami secara bersama sama menilai dan memutuskan apakah kasus tersebut dapat diselesaikan secara kekeluargaan atau tidak". ${ }^{23}$

Berdasarkan hasil

penelitian yang dilakukan tentang penerapan diskresi kepolisian dalam penanganan tindak pidana kecelakaan lalu lintas di wilayah hukum Polres Purbalingga yang melibatkan pejalan kaki dan kendaraan tidak bermotor pada tahun 2014 s/d 2016, diperoleh data sebagaimana tertuang dalam tabel sebagai berikut :
${ }^{23}$ Lihat hasil wawancara dengan IPTU Riyatnadi selaku Anggota Penyidik Laka Lakas Polres Purbalingga, tentang kecelakaan lalu lintas yang melibatkan pejalan kaki di wilayah hukum Polres Purbalingga 20 Juni 2017. 
Tabel 2: Data laka lantas yang melibatkan pejalan kaki di wilayah hukum Polres Purbalingga tahun 2014

\begin{tabular}{|c|c|c|c|c|c|c|c|c|c|}
\hline \multirow{2}{*}{ No } & \multirow{2}{*}{$\begin{array}{c}\text { Laka } \\
\text { Lant } \\
\text { as }\end{array}$} & \multirow{2}{*}{$\begin{array}{c}\text { Jml } \\
\text { Laka } \\
\text { Lant } \\
\text { as }\end{array}$} & \multicolumn{2}{|c|}{$\begin{array}{c}\text { Korba } \\
n\end{array}$} & \multicolumn{5}{|c|}{ Saikara } \\
\hline & & & $\begin{array}{ll}M & L \\
D & B\end{array}$ & $\begin{array}{l}\mathbf{L} \\
\mathbf{R}\end{array}$ & $\begin{array}{l}\text { Lim } \\
\text { PU }\end{array}$ & $\begin{array}{l}\mathrm{S} \\
\mathrm{P} \\
3\end{array}$ & $\begin{array}{l}\mathbf{R} \\
\mathbf{J}\end{array}$ & $\begin{array}{l}\mathrm{L} \\
\mathrm{i} \\
\mathrm{m}\end{array}$ & $\begin{array}{l}\mathrm{Li} \\
\mathbf{d i} \\
\mathrm{k} / \\
\mathrm{Si} \\
\mathrm{di} \\
\mathbf{k}\end{array}$ \\
\hline
\end{tabular}

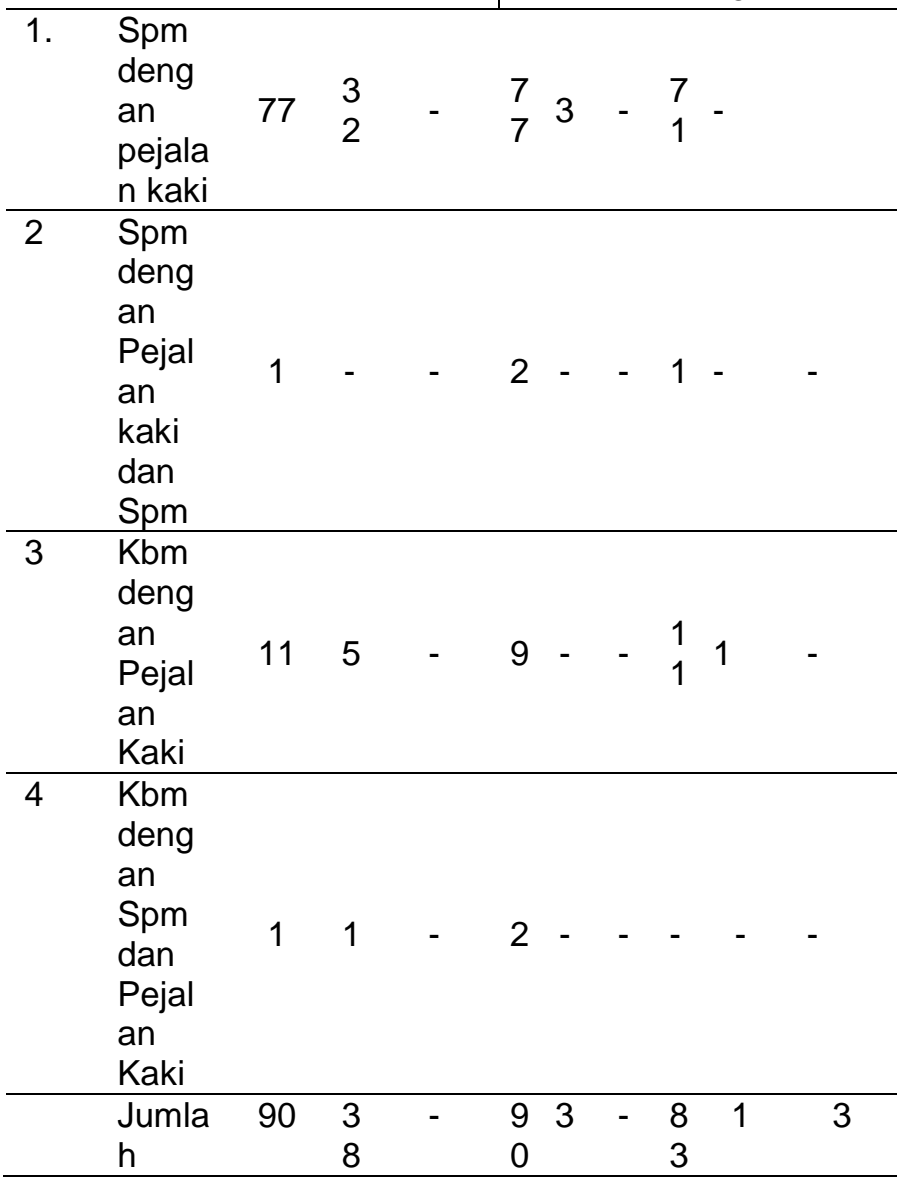

* Sumber: Satlantas Polres Purbalingga
Berdasarkan Tabel 2 tersebut di atas, maka dapat diketahui bahwa jumlah kecelakaan lalu lintas antara Sepeda motor dengan penjalan kaki, Kendaraan bermotor dengan pejalan kaki, sejumlah 90 kasus dengan korban meninggal dunia sejumlah 38 orang, korban luka berat tidak ada, korban luka ringan sejumlah 90 orang.

Dalam tahun 2014 penyelesaian perkara tindak pidana kecelakaan lalu lintas yang melibatkan pejalan kaki di wilayah hukum Polres Purbalingga, adalah sebagai berikut : Limpah PU sejumlah 3 kasus, SP 3 tidak ada, RJ sejumlah 83 kasus, dan Limpah Provost sejumlah 1 kasus, serta Lidik/Sidik sejumlah 3 kasus tabrak lari. 
1007 | Jurna | I dea H u kum

VoI. 4 No.2 Oktober 2018

Magister Hukum Fakultas Hukum

Universitas Jenderal Soedirman

Tabel 3: : Data laka lantas yang melibatkan pejalan kaki di wilayah hukum Polres Purbalingga Tahun 2015

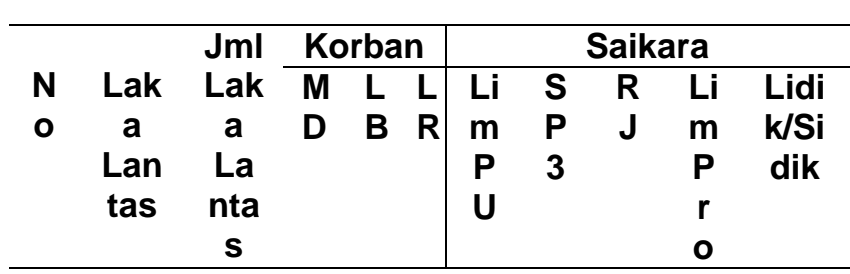

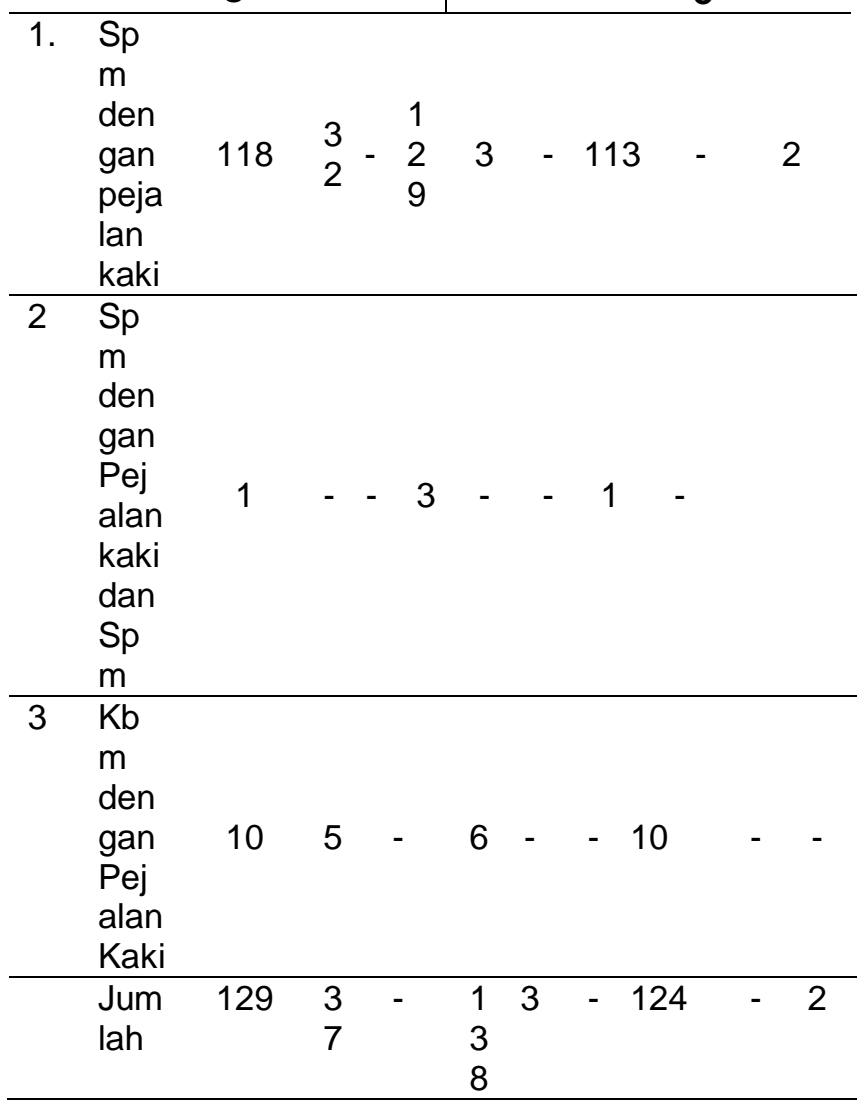

* Sumber: Satlantas Polres Purbalingga
Berdasarkan data laka lantas yang melibatkan pejalan kaki di wilayah hukum Polres Purbalingga Tahun 2015 sebagaimana tertuang dalam Tabel 3 tersebut di atas, maka dapat diketahui bahwa kecelakaan lalu lintas pada tahun 2015 antara Sepeda Motor dengan Pejalan Kaki sejumlah 129 kasus dengan korban meninggal dunia sejumlah 37 orang, korban luka berat tidak ada, korban luka ringan sejumlah 138 orang.

Dalam tahun 2015 berdasarkan Tabel 3 tersebut di atas, maka dapat di kemukakan sebagai berikut : Limpah PU sejumlah 3 kasus, SP3 tidak ada kasus yang dilimpahkan, RJ sejumlah 124 kasus, dan Limpah Provost tidak ada kasus yang dilimpahkan, sedangkan Lidik/Sidik sejumlah 2 kasus tabrak lari. Jumlah kasus kecelakaan lalu lintas yang melibatkan pejalan kaki pada tahun 2105 lebih banyak yaitu mencapai 129 kasus dari tahun sebelumnya yaitu tahun 2014 yang hanya 90 kasus. 
Tabel 4 : Data laka lantas yang melibatkan pejalan kaki di wilayah hukum Polres Purbalingga Tahun 2016

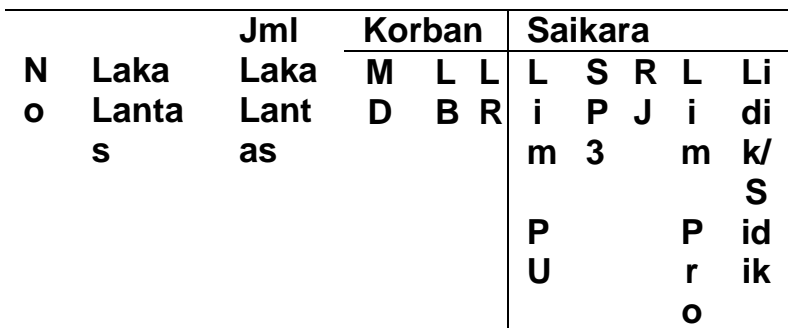

\begin{tabular}{|c|c|c|c|c|c|c|c|c|c|}
\hline 1. & $\begin{array}{l}\text { Spm } \\
\text { denga } \\
n \\
\text { pejala } \\
n \text { kaki }\end{array}$ & 140 & $\begin{array}{l}3 \\
1\end{array}$ & 6 & $\begin{array}{ll}1 & \\
6 & 2 \\
2 & \end{array}$ & & $\begin{array}{l}1 \\
3 \\
5\end{array}$ & & 4 \\
\hline 2 & $\begin{array}{l}\text { Kbm } \\
\text { denga } \\
n \\
\text { Pejala } \\
\text { n Kaki }\end{array}$ & 11 & 6 & -8 & 8 & & $\begin{array}{l}1 \\
0\end{array}$ & - & - \\
\hline 3 & $\begin{array}{l}\text { Kbm } \\
\text { denga } \\
\text { n } \\
\text { Pejala } \\
\text { n Kaki } \\
\text { denga } \\
\text { n Kbm }\end{array}$ & 1 & 1 & - & - & & 1 & - & - \\
\hline 4 & $\begin{array}{l}\text { Kbm } \\
\text { denga } \\
\mathrm{n} \mathrm{Kbm} \\
\text { denga } \\
\text { n Spm } \\
\text { denga } \\
\text { n } \\
\text { Pejala } \\
\text { n kaki } \\
\text { dan } \\
\text { denga } \\
\text { n Kbm }\end{array}$ & 1 & - & -1 & 1 & & 1 & - & - \\
\hline 5 & $\begin{array}{l}\text { Kbm } \\
\text { denga } \\
\text { n } \\
\text { pejala } \\
\text { n kaki } \\
\text { denga } \\
\text { n Spm }\end{array}$ & 1 & 1 & & 5 & & 2 & - & - \\
\hline & $\begin{array}{l}\text { Jumla } \\
\mathrm{h}\end{array}$ & 155 & $\begin{array}{l}3 \\
8\end{array}$ & & $\begin{array}{ll}1 & 2 \\
7 & \\
6 & \end{array}$ & & $\begin{array}{l}1 \\
4 \\
9\end{array}$ & - & 4 \\
\hline
\end{tabular}

*Sumber: Satlantas Polres Purbalingga
Kecelakaan lalu lintas

antara Sepeda Motor dengan

kendaraan bermotor yang

melibatkan Pejalan kaki, di

wilayah hukum Polres

Purbalingga dalam Tabel 4

tersebut di atas dapat diketahui bahwa pada Tahun 2016 terdapat 155 kasus. Dalam kecelakaan lalu lintas tersebut yang meninggal dunia sejumlah 38 orang, luka berat tidak ada, sedangkan yang me ngalami luka ringan sejumlah 176 orang.

Dalam tebel tersebut di atas, dapat diketahui bahwa penyelesaian perkara tindak pidana kecelakaan lalu lintas yang melibatkan pejalan kaki di wilayah hukum Polres Purbalingga dalam tahun 2016 untuk limpah PU sejumlah 2 kasus, SP3 tidak ada, RJ sejumlah 149 kasus, Limpah Provost tidak ada, Lidik/Sidik sejumlah 4 kasus tabrak lari.

Memperhatikan tabeltabel tersebut di atas (Tabel 2, 3 dan 4) tentang data laka lantas yang melibatkan pejalan kaki di wilayah hukum Polres Purbalingga Tahun 2014, 2015 dan Tahun 2016, bahwa kecelakaan lalu lintas yang melibatkan pejalan kaki lebih banyak dilanggar oleh pengendara Sepeda motor. Jumlah kecelakaan lalu lintas yang melibatkan pejalan kaki 
setiap tahun bertambah, pada

tahun 2014 sejumlah 90 kasus,

tahun 2015 sejumlah 129 dan

pada tahun 2016 sejumlah 155

kasus. Penyelesaian perkara

tindak pidana kecelakaan lalu

lintas yang melibatkan pejalan

kaki di wilayah hukum Polres

Purbalingga lebih banyak

diselesaikan melalui Restorative

Justice merupakan alternatif

penyelesaian sengketa yang

dilakukan di luar pengadilan.

Dijelaskan oleh anggota penyidik bahwa ada beberapa hal yang menjadi Pertimbangan dalam pelaksanaan diskresi, yaitu:

a. Aspek Sosiologis, apabila dari para pihak sudah menerima/saling memaafkan sehingga apabila kita memandang dari asas kemanfaatan dan asas keadilan kedua asas tersebut sudah terpenuhi.

b. Aspek Filosofis, yang dalam hal ini harus tercapai tujuan hukum yaitu terpenuhinya asas kepastian hukum, asas kemanfaatan, dan asas keadilan.

c. Aspek Yuridis, merupakan aspek yang melandasi aturan hukum yang berlaku, yang dalam hal ini adalah aturan tentang penyelesaian kasus kecelakaan diluar jalur hukum/pengadilan. ${ }^{24}$

Dengan adanya peraturan dan perundangan yang

${ }^{24}$ Lihat hasil wawancara dengan IPTU Riyatnadi selaku Anggota Penyidik Laka Lakas Polres Purbalingga, tentang kecelakaan lalu lintas yang melibatkan pejalan kaki di wilayah hukum Polres Purbalingga 20 Juni 2017. diberlakukan untuk mengatur kegiatan di bidang lalu lintas, maka penegakan hukum tersebut diberlakukan sesuai dengan tujuannya, yaitu memulihkan terganggunya keseimbangan antara kepentingan individu dengan individu ataupun kepentingan individu dengan kepentingan umum. Selain itu juga dipergunakan untuk memelihara keamanan, ketertiban dan memberikan perlindungan dan pengayoman kepada masyarakat khususnya kepada masyarakat sebagai pemakai jalan. ${ }^{25}$

Sehubungan dengan adanya perkara kecelakaan lalu lintas diproses melalui peradilan pidana sesuai dengan ketentuan peraturan perundang-undangan, Barda Nawawi Arief mengemukakan, walaupun pada umumnya penyelesaian sengketa di luar pengadilan hanya ada dalam sengketa perdata, namun dalam praktik sering juga kasus pidana diselesaikan di luar pengadilan melalui berbagai diskresi aparat penegak hukum atau melalui mekanisme musyawarah/perdamaian atau lembaga permaafan yang ada di dalam masyarakat (musyawarah

25 Faal, 1991. Op. cit. 68 
keluarga, musyawarah desa, musyawarah adat dsb.). ${ }^{26}$

Pertimbangan

yang

diperlukan dalam pelaksanaan

diskresi, apabila Ditinjau dari asas

kemanfaatan, menurut penjelasan

yang disampaikan oleh Kasat

Lantas Polres Purbalingga

sebagai berikut :

"Penyidik menimbang, bahwa suatu perkara laka lantas akan lebih bermanfaat bagi para pihak apabila diselesaikan secara musyawarah dan penyidikan juga akan lebih efisien, mengingat jumlah kasus kecelakaan yang terjadi tidak sedikit, dan akan memakan waktu yang lama apabila semua kasus diselesaikan melalui jalur hukum. Keterlambatan proses penyidikan akan menyebabkan penumpukan kasus dan dapat berdampak pada menurunnya kepercayaan masyarakat (Public Trust) terhadap polisi, dan tidak menutup kemungkinan akan menuai banyak komplain dari masyarakat tentang pelayanan kepolisian". 27

\section{Terhadap penjelasan} sebagaimana tersebut di atas lebih lanjut narasumber mengemukakan sebagai berikut:

"Penanganan perkara laka lantas tidak hanya sebatas penyidikan dan penegakan hukum saja, tetapi juga merupakan salah satu bentuk pelayanan polisi terhadap

26 Barda Nawawi Arief, 2006.

Op. cit. hlm. 3

${ }_{27}$ Lihat hasil wawancara dengan AKP Sukarwan , S.H., M.M selaku Kasat Lantas Polres Purbalingga. 21 Juni 2017 masyarakat hal ini berdasarkan Pasal 13 UU 2 Tahun 2002 tentang Kepolisian Negara Republik Indonesia yang mengatur Tupoksi Anggota Polri. Proses Penanganan Kecelakaan Lalu Lintas dimulai dari TPTKP, Olah TKP, Evakuasi Korban, Mencari Saksi, Evakuasi Barang Bukti, Pendataan, Pengurusan Jasa Raharja, Mediasi Hingga Proses Penyidikan yang membutuhkan waktu tidak singkat.

Dalam penanganan laka lantas walaupun akan menempuh jalur hukum suatu kasus kecelakaan harus dimediasi terlebih dahulu mengingat dalam UU No 22 tahun 2009 yang mengungkapkan kewajiban pelaku untuk mengganti rugi/menyantuni pihak yang dirugikan, sehingga harus dimediasi untuk mengahasilkan kesepakatan mengenai ganti rugi tersebut. Selain itu dengan tidak menuntutnya korban ke ranah hukum dengan produk surat pernyataan perdamaian yang dilampirkan dalam berkas perkara akan memperingan vonis yang akan dijatuhkan oleh hakim pada saat persidangan. Dan proses mediasi ini pun membutuhkan waktu yang tidak singkat, mulai dari pemanggilan keluarga korban, mengatur jadwal pertemuan, hingga tercapainya kesepakatan, tidak bisa sehari jadi”. ${ }^{28}$

Terhadap pernyataan yang dikemukakan oleh Barda Nawawi Arief tersebut di atas, Sunaryati Hartono menyatakan mendukung adanya alternatif lain

${ }^{28}$ Lihat hasil wawancara dengan AKP Sukarwan , S.H., M.M selaku Kasat Lantas Polres Purbalingga. 21 Juni 2017 
1011 | Jurna | | dea H u kum

Vol. 4 No.2 Oktober 2018

Magister Hukum Fakultas Hukum

Universitas Jenderal Soedirman

dalam penyelesaian

perkara/sengketa di luar proses

litigasi, dengan alasan bahwa

penegakan hukum itu hendaknya

tidak dilakukan secara harfiah

atau secara formalitas belaka,

tetapi benar-benar dilakukan

dengan maksud untuk

menciptakan keadilan, baik bagi

para pihak yang

berperkara/bersengketa maupun

bagi masyarakat luas. ${ }^{29}$

Bagi petugas Polantas,

menegakkan hukum memang

hasus diyakini sebagai tindakan

dengan tujuan berikut : Pertama,

menyelesaikan konflik atau

masalah dengan cara yang

beradab melalui pemetaan dan

mencari akar masalah untuk

menemukan solusi yang

bermanfaat bagi terpeliharanya

Keamanan, keselamatan,

ketertiban, dan kelancaran lalu

lintas (Kamseltibcar Lantas).

Kedua, memiliki kepekaan, kepedulian, keberanian dan

kemampuan mencegah terjadinya masalah yang lebih luas. Ketiga, melindungi, mengayomi, serta melayani korban maupun pencari keadilan dalam rangka mendukung produktifitas dan melindungi harkat serta martabat manusia. Keempat, melakukan tindakan edukasi yang dapat

29 Sunaryati Hartono, 1991. Op. cit. Hal. 26. membangun kepekaan atau kepedulian pada Kamseltibcar Lantas. Kelima, menciptakan kepastian hukum yang dapat menjadi sandaran bagi pemecahan masalah. $^{30}$

Sehubungan dengan penjelasan tersebut di atas, menurut Chrysnanda Dwilaksana, $^{31}$ bahwa untuk mengimplementasikan Gakkum Lantas (Penegakan Hukum Lalu Lintas), ada sembilan langkah yang dapat dilakukan:

a. Memetakan wilayah, masalah, dan potensinya;

b. Membuat standar keamanan, keselamatan, ketertiban, dan kelancaran lalu lintas (Kamseltibcar Lantas) yang dapt dijadikan pedoman bagi upaya Gakkum yang dapat dijadikan pedoman bagi upaya Gakkum;

c. Membuat MoU dengan unsur CJS (Criminal Justice System) lainnya;

d. Membentuk forum yang berisi representasi dari seluruh pemangku kepentingan;

e. Menyiapkan sistem on line baik untuk control dan Gakkum;

f. Menyiapkan soft ware dan hard ware pendukung electronic enforcement.

g. Menyiapkan sumber daya manusia (penyidik yang professional);

30 Chryshnanda Dwilaksana, 2011. Kenapa Mereka Takut dan Enggan Berurusan Dengan Polisi ? Sebuah Catatan Harian. Yayasan Pengembangan Kajian IImu Kepolisian (YPKIK), Jakarta. hlm. 8

31 Ibid., hlm. 9 
h. Mendorong pengkajian dan pembenahan sistem pendanaan untuk pengadaan dan perawatan infrastrukstur lalu lintas;

i. Membangun system $\mathrm{K} 3 \mathrm{i}$ Komunikasi, Koordinasi, Komando dan kendali, dan Informasi) untuk menciptakan keterpaduan yang berkesinambungan;

Pemikiran-pemikiran kritis atas sistem yang ada dalam mewujudkan dan pemeliharaan Kamseltibcar Lantas memang bukan hal mudah, tetapi terus dirintis dan diperjuangkan.

\section{Diskresi}

Kepolisian sebagaimana dimaksud Pasal 18 Undang-undang Nomor 2 Tahun 2002

Perjalanan masyarakat yang terus berkembang dengan kemungkinan diikuti meluasnya konflik-konflik sosial yang meliputi aspek politik, ekonomi, dan sosial budaya pada masa kini atau yang akan datang, sehingga konflik tersebut dapat dirasakan sangat merugikan serta membahayakan kehidupan masyarakat. Konflik sosial yang demikian itu memerlukan hukum yang disusun dengan orientasi ke masa depan yakni tidak hanya berlandaskan kaidah yang sudah berlaku saja, melainkan harus berlandaskan nilai-nilai baru yang tumbuh dalam masyarakat, asas-asas hukum yang diakui oleh dunia internasional, penyesuaian dengan konvensi internasional, dan mengakui hukum sebagai realita sosial atau ius operatum. ${ }^{32}$

Berdasarkan Undangundang Nomor 2 Tahun 2002 tentang Kepolisian Negara Republik Indonesia, dalam Pasal 2 ditegaskan bahwa:

"Fungsi kepolisian adalah salah satu fungsi pemerintahan negara di bidang pemeliharaan keamanan dan ketertiban masyarakat, penegakan hukum, perlindungan, pengayoman, dan pelayanan kepada masyarakat".

Dalam Pasal 4 Undangundang Nomor 2 Tahun 2002 tentang Kepolisian Negara Republik Indonesia, dirumuskan tentang tujuan Kepolisian Negara Republik Indonesia yang perumusannya sebagai berikut:

"Kepolisian Negara Republik Indonesia bertujuan untuk mewujudkan keamanan dalam negeri yang meliputi terpeliharanya keamanan dan ketertiban masyarakat, tertib dan tegaknya hukum, terselenggaranya perlindungan, pengayoman, dan pelayanan masyarakat, serta terbinanya ketenteraman masyarakat dengan menjunjung tinggi hak asasi manusia".

32 Bambang Purnomo, 1984. Pertumbuhan Hukum Penyimpangan di luar Kodifikasi Hukum Pidana . Cetakan Pertama. Bina Aksara, Jakarta. hlm. 4

${ }_{33}$ Pasal 2 dan 4 Undang-undang No. 2 Tahun 2002 tentang Kepolisian Negara Republik Indonesia 
1013 | Jurna I I de a H u kum

Vol. 4 No. 2 Oktober 2018

Magister Hukum Fakultas Hukum

Universitas Jenderal Soedirman

Dalam Penjelasan Umum

Undang Nomor 2 Tahun 2002

tentang Kepolisian Negara

Republik Indonesia, secara tegas

dijelaskan bahwa:

tetap “... tindakan pencegahan pengembangan asas preventif dan asas kewajiban umum kepolisian, yaitu memelihara keamanan dan ketertiban masyarakat. Dalam hal ini setiap pejabat Kepolisian Negara Republik Indonesia memiliki kewenangan diskresi, yaitu kewenangan untuk bertindak demi kepentingan umum berdasarkan penilaian sendiri". Kewenangan-kewenangan sebagaimana dijalaskan dalam penjelasan umum tersebut di atas rupanya belum mampu untuk mengatur seluruh tindakan kepolisian secara eksplisit, definitif dan limitatif, termasuk pula kewenangan penggunaan diskresi kepolisian. Oleh karenanya tindakan diskresi sebagai tindakan yang didasarkan atas penilaiannya sendiri itu dibatasi menurut ketentuan perundang-undangan dank ode etik profesi kepolisian dengan senantiasa memperhatikan norma-norma keagamaan, perikemanusiaan, kesopanan dan kesusilaan. Dengan demikian polisi diberi wewenang untuk bertindak apapun yang dianggap perlu sesuai dengan tujuan tugas kepolisian.

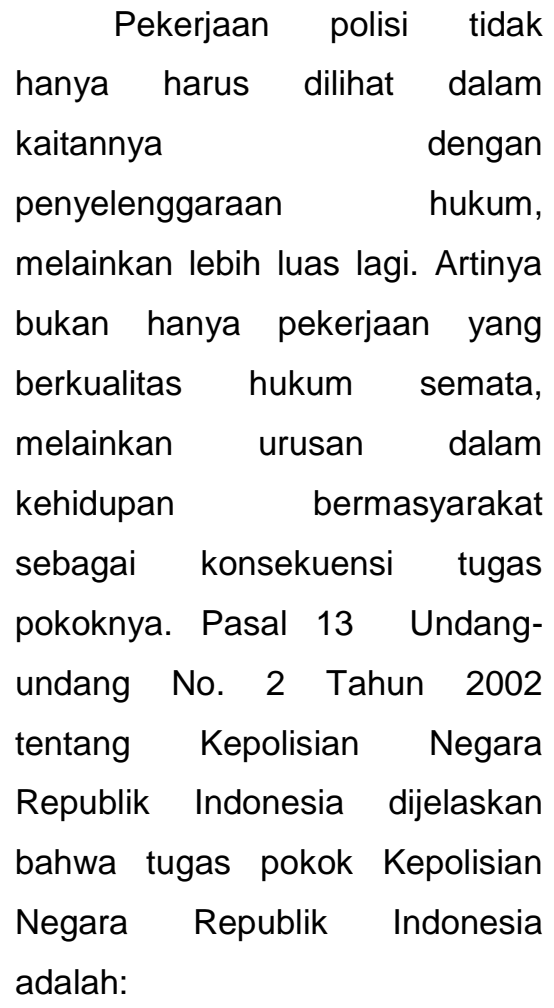

a. memelihara keamanan dan ketertiban masyarakat;

b. menegakkan hukum; dan

c. memberikan perlindungan, pengayoman, dan pelayanan kepada masyarakat.

Sehubungan dengan adanya tugas pokok kepolisian tersebut di atas, tidak hanya bisa dikaitkan pada penyelenggaraan hukum dalam arti sempit saja. Menurut Satjipto Rahardjo dan Anton Tabah, ${ }^{34}$ bahwa:

"Memelihara dan mencegah tersebut membutuhkan kreativitas. Pada giliannya kreativitas itu menumbuhkan kelonggaran dan kebebasan dalam bertindak dan berarti tugas

34 Satjipto Rahardjo dan Anton Tabah. 1993. Polisi: Perilaku dan Pemikir, Gramedia Pustaka Utama, Jakarta, hlm 28 
polisi tidak bisa diatur dan dibatasi atau dalam istilah ilmunya dibutuhkan suatu diskresi untuk bisa melaksanakan tugas tersebut".

Lebih lanjut Satjipto Rahardjo mengemukakan :

"Hukum itu hanya dapat menuntun kehidupan bersama secara umum, sebab begitu ia mengatur secara sangat terperinci, dengan memberikan skenario langkah-langkah secara lengkap, maka pada waktu itu pula kehidupan akan macet. Oleh karena itu sesungguhnya diskresi merupakan kelengkapan dari sistem pengaturan oleh hukum itu sendiri". ${ }^{35}$

Landasan hukum terhadap diskresi kepolisian sebagai legitimasi atas dipergunakannya wewenang diskresi oleh Kepolisian Negara Republik Indonesia dikemukakan oleh Sukarwan ${ }^{36}$ sebagai berikut :

"Agar semua pihak terlindung baik dari pihak polisi maupun masyarakat, dasar hukum pelaksanaan kewenangan diskresi kepolisian, bahwa aspek yuridis merupakan aspek yang melandasi aturan hukum yang berlaku, yang dalam hal ini adalah aturan tentang penyelesaian kasus kecelakaan diluar jalur hukum/pengadilan. Aturan-aturan tersebut diantaranya :

a. Pasal 18 UU No. 2 Tahun 2002 Tentang Kepolisian

35 Satjipto Rahardjo, 1983. Masalah Penegakan Hukum, Sinar Baru, Bandung, hlm. 11

${ }^{36}$ Lihat hasil wawancara dengan AKP Sukarwan, S.H., M.M selaku Kepala Satuan Lalu Lintas Polres Purbalingga
Negara Republik Indonesia (Mengatur tentang diskresi kepolisian)

b. Pasal 13 UU No. 2 Tahun 202 Tentang Kepolisian Negara Republik Indonesia (yang mengatur bahwa tupoksi Polri tidak hanya penegakan hukum tapi melayani masyarakat dan memelihara keamanan dan ketertiban masyarakat).

c. Pasal 63 Peraturan Kepala Kepolisian Negara Republik Indonesia (Perkap) No. 15 Tahun 2013 tentang tata cara Penanganan Kecelakaan Lalu Lintas (Mengatur Penyelesaian Perkara Kecelakaan Lalu Lintas Ringan)

d. Surat Kapolri No. Pol. : B/3022/XII/209/SDEOPS

Tanggal 14 Desember 209 tentang penanganan kasus melalui "Alternative Dispute Resolution/ ADR"

e. Surat Telegram Reskrim (STR) Kabareskrim Polri No. ST/110/V/2011, tanggal 18 Mei 2011 tentang Pedoman Penerapan ADR di Jajaran Reskrim Polri.

f. Surat Telegram Kapolda Jateng Nomor : ST/186/III/2015 tanggal 26 Maret 2015 tentang Penanganan Perkara Laka Lantas dimana terdapat hubungan kekerabatan yang erat antara pelaku dan korban.

Dalam kaitannya dengan tugas kepolisian Undang-undang No. 2 Tahun 2002 tentang Kepolisian Negara Republik Indonesia telah memberikan kewenangan kepada polisi untuk melakukan tindakan dan penilaian sendiri yang dapat dipertanggungjawabkan secara hukum atau yang lazim disebut diskresi polisi. Terhadap 
1015 | Jurna | I de a H u kum

VoI. 4 No.2 Oktober 2018

Magister Hukum Fakultas Hukum

Universitas Jenderal Soedirman

kebenaran dan keabsahan

dilakukannya tindakan diskresi

polisi tersebut, Pudi Rahardi

mengemukakan bahwa diskresi

polisi secara formal diatur dalam

Pasal 18 Undang-Undang No. 2

Tahun 2002 tentang Kepolisian

Negara Republik Indonesia, yang

menyebutkan bahwa :

(1) Untuk kepentingan umum, pejabat Kepolisian Negara Republik Indonesia dalam melaksanakan tugas dan wewenangnya dapat bertindak menurut penilaiannya sendiri.

(2) Pelaksanaan ketentuan sebagaimana dimaksud dalam ayat (1) hanya dapat dilakukan dalam keadaan yang sangat perlu dengan memperhatikan peraturan perundang-undangan, serta Kode Etik Profesi Kepolisian Negara Republik Indonesia. ${ }^{37}$

Kepentingan umum sangat erat hubungannya dengan masalah sosial, pengertian "kepentingan umum" sebagaimana dimaksud pada Pasal 18 ayat (1) tersebut di atas telah didefinisikan sebagaimana terdapat dalam Pasal 1 butir 7 Undang-Undang No. 2 Tahun 2002 tentang Kepolisian Negara Republik Indonesia, berbunyi :

"Kepentingan umum adalah kepentingan masyarakat dan/atau

37 H. Pudi Rahardi, 2007. Hukum Kepolisian (Profesionalisme dan Reformasi POLRI). Laksbang Mediatama, Surabaya. hlm. 98 kepentingan bangsa dan negara demi terjaminnya keamanan dalam negeri".

Selanjutnya pengertian "bertindak menurut penilaiannya sendiri" dijelaskan dalam penjelasan Pasal 18 Ayat (1) sebagai berikut :

"Yang dimaksud dengan "bertindak menurut penilaiannya sendiri" adalah suatu tindakan yang dapat dilakukan oleh anggota Kepolisian Negara Republik Indonesia yang dalam bertindak harus mempertimbangkan manfaat serta risiko dari tindakannya dan betul-betul untuk kepentingan umum".

Salah satu kewenangan melakukan tindakan diskresi polisi, sebagaimana dijelaskan dalam Pasal 16 ayat (1) butir $L$, dan ayat (2) Undang-undang Nomor 2 Tahun 2002 tentang Kepolisian Negara Republik Indonesia. Pasal 16 ayat (1) butir L yaitu : "Mengadakan tindakan lain menurut hukum yang bertanggung jawab". Pasal 16 ayat (2) yaitu: "Tindakan lain sebagaimana dimaksud dalam ayat (1) huruf $L$ adalah tindakan penyelidikan dan penyidikan yang dilaksanakan jika memenuhi syarat sebagai berikut :

a. tidak bertentangan dengan suatu aturan hukum;

b. selaras dengan kewajiban hukum yang mengharuskan tindakan tersebut dilakukan; 
c. harus patut, masuk akal, dan termasuk dalam lingkungan jabatannya;

d. pertimbangan yang layak berdasarkan keadaan yang memaksa; dan

e. menghormati hak asasi manusia".

$$
\text { Meskipun polisi itu }
$$

bertindak seolah-oleh justru tidak berdasarkan hukum positif yang berlaku dengan melakukan tindakan penyaringan. Tindakan diskresi polisi yang dilakukan dalam kerangka hukum yang dimaksud adalah bahwa tindakan itu dapat dipertanggungjawabkan secara hukum dengan alasan yang didasari demi kepentingan umum. Karena memang kerangka hukum dilakukannya diskresi adalah dalam rangka melindungi kepentingan umum.

Hakekat tugas dan tanggung jawab yang dijalankan kepolisian tertuju pada tercipta dan terwujudnya rasa aman, tenteram, tertib, dan damai dalam kehidupan masyarakat. Tugas mewujudkan rasa aman, tenteram, tertib dan damai sebagai suatu amanah dan dimiliki nilai kemanusiaan yang tinggi, di mana aktivitas kehidupan manusia menjadi aman, tenteram, tertib dan damai oleh karena karya dan karsa kepolisian. Di sini terletak nilainilai kemanusiaan yang terkandung dalam tugas-tugas kepolisian. Konsekuensi logisnya pejabat kepolisian dituntut untuk memahami nilai-nilai kemanusiaan dalam tugas yang dimaksud, sehingga apa yang dijalankan tidak akan menggeser nilai yang telah ada dan terkandung dalam tugas. Terjadinya perubahan dan pergeseran nilai tugas, berarti merubah dan mempengaruhi hakekat tugas dan wewenang yang diamanatkan. ${ }^{38}$

Berdasarkan penjelasan di atas, maka dapat difahami bahwa diskresi itu sesungguhnya suatu keputusan atau tindakan kepolisian yang dengan sadar tidak melakukan kewajiban atau tugas selaku penegak hukum berdasarkan alasan-alasan yang dapat dipertanggungjawabkan terhadap hukum itu sendiri. Menurut Satjipto Rahardjo, bahwa: "Pemikiran kebijaksanaan diskresi bisa mengadakan kompromi antara keharusankeharusan yang diletakkan dalam peraturan-peraturan hukum dengan keleluasaan bertindak". ${ }^{39}$ Sehubungan dengan wewenang diskresi, berikut pernyataan dari narasumber mengenai akibat hukum apabila

38 Sadjijono, 2006. Hukum Kepolisian: Perspektif Kedudukan Kepolisian dan Hubungannya dalam Hukum Administrasi. Laksbang, Yogyakarta. hlm. 47

39 Satjiptp Rahardjo, 1994. Sosiologi Hukum, Makalah Kuliah S2, Ilmu Hukum,Undip, Semarang. 
1017 | Jurna | I dea Hukum

VoI. 4 No.2 Oktober 2018

Magister Hukum Fakultas Hukum

Universitas Jenderal Soedirman

para pihak tidak melaksanakan

kesepakatan terhadap hal

tersebut narasumber,

40

memberikan penjelasan, sebagai

berikut : "Akibat hukum yang

diterima apabila para pihak tidak

melaksanakan kesepakatan yaitu

sesuai kesepakatan yang tertulis

dalam surat pernyataan siap

menerima sanksi hukum yang

berlaku, maka jalur hukum harus ditempuh".

Petugas Kepolisian harus memutuskan untuk mengambil tindakan lain yang lebih sesuai dengan tingkat dari sifat gangguan yang dihadapinya.

Dalam mengambil tindakan berdasarkan penilaian sendiri, yang paling menentukan kualitas tindakan adalah kemampuan dan pengalaman petugas Kepolisian yang mengambil tindakan tersebut. Oleh karena itu, pemahaman tentang "Diskresi Kepolisian" dalam Pasal 18 ayat (1) harus dikaitkan juga dengan pembinaan profesi yang diatur dalam Pasal 31, 32, 33, Undangundang Nomor : 2 Tahun 2002 sehingga terlihat adanya jaminan bahwa petugas Kepolisian Negara Republik Indonesia akan mampu mengambil tindakan secara tepat dan profesional

${ }^{40}$ Hasil wawancara dengan AKP Sukarwan, S.H., M.M selaku Kasat Lantas Polres Purbalingga. 21 Juni 2017 berdasarkan penilaiannya sendiri dalam rangka pelaksanaan tugasnya.

Dalam melakukan tindakan sendiri tersebut atau dengan kata lain penggunaan diskresi oleh anggota Kepolisian Negara Republik Indonesia harus dilakukan dalam keadaan yang sangat perlu atau mendesak dengan memperhatikan peraturan perundang-undangan dan Kode Etik Profesi Kepolisian Negara Republik Indonesia (Pasal 18 ayat (2) Undang-undang Nomor : 2 Tahun 2002). Ketentuan tersebut merupakan rambu-rambu pembatasan bagi pelaksanaan diskresi oleh anggota Kepolisian Negara Republik Indonesia sebagaimana dimaksud pada Pasal 18 ayat (1) yaitu selain harus mematuhi asas keperluan, tindakan diskresi tetap harus sesuai dan memperhatikan peraturan perundang-undangan serta Kode Etik Profesi Kepolisian Negara Republik Indonesia. Hal itu dimaksudkan agar anggota Kepolisian Negara Republik Indonesia tidak bertindak sewenang-wenang atau melanggar ketentuan yang berlaku atau melakukan tindakan yang berlebihan di dalam 


$\begin{aligned} & \text { menggunakan } \\ & \text { diskresinya. }\end{aligned}{ }^{41}$ kewenangan
Berkaitan $\begin{array}{rr}\text { dengan } \\ \text { pelaksanaan tugas } & \text { dan } \\ \text { wewenang Kepolisian } & \text { Negara } \\ \text { Republik Indonesia, Pudi } & \text { Pahardi }{ }^{42} \text { mengemukakan bahwa } \\ \text { dalam Pasal } 19 \text { Undang-Undang } \\ \text { No. } 2 \text { Tahun } 2002 \text { disebutkan, } \\ \text { bahwa: }\end{array}$

(1) Dalam melaksanakan tugas dan wewenangnya, pejabat Kepolisian Negara Republik Indonesia senantiasa bertindak berdasarkan norma hukum dan mengindahkan noma agama, kesopanan, kesusilaan, serta menjunjung tinggi hak asasi manusia;

(2) Dalam melaksanakan tugas dan wewenang sebagaimana dimaksud dalam ayat (1), Kepolisian Negara Republik Indonesia mengutamakan tindakan pencegahan.

Pasal 19 ayat (2) mengisyaratkan bahwa dalam setiap segi pelaksanaan tugas pokok harus dirasakan adanya nuansa dan karakter Kepolisian selaku pelindung, pengayom dan pelayan masyarakat, yang pelaksanaannya dikaitkan dengan tataran fungsi Kepolisian yang terdiri atas:

a. Tataran represif yustitisial yang mengutamakan asas legalitas. hlm. 100

H. Pudi Rahardi, 2007. Op. cit. ${ }^{42}$ Ibid., hlm. 101 b. Tataran represif non yustisial penindakan Kepolisian yang menggunakan asas preventif dan asas kewajiban umum Kepolisian.

c. Tataran preventif dan preemptive yang menggunakan asas preventif, asas partisipasi dan asas subsidiaritas.

Memperhatikan pendapat Pudi Rahardi tersebut di atas, maka Polisi dalam melaksanakan tugas dan wewenang hendaknya memperhatikan Kode Etik Profesi Kepolisian Negara Republik Indonesia, Undang-undang Nomor 2 Tahun 2002 tentang Kepolisian Negara Republik Indonesia Pasal 31, 32, 33 menyebutkan :

Pasal 31

Pejabat Kepolisian Negara Republik Indonesia dalam melaksanakan tugas dan wewenangnya harus memiliki kemampuan profesi.

\section{Pasal 32}

(1) Pembinaan kemampuan profesi pejabat Kepolisian Negara Republik Indonesia diselenggarakan melalui pembinaan etika profesi dan pengembangan pengetahuan serta pengalamannya di bidang teknis kepolisian melalui pendidikan, pelatihan, dan penugasan secara berjenjang dan berlanjut.

(2) Pembinaan kemampuan profesi sebagaimana 
1019 | Jurna I I dea Hukum

VoI. 4 No.2 Oktober 2018

Magister Hukum Fakultas Hukum

Universitas Jenderal Soedirman

dimaksud dalam ayat (1) diatur lebih lanjut dengan Keputusan Kapolri.

\section{Pasal 33}

Guna menunjang pembinaan profesi sebagaimana dimaksud dalam Pasal 32 dilakukan pengkajian, penelitian, serta pengembangan ilmu dan teknologi kepolisian.

Terhadap anggota polisi yang karena kelalaiannya atau kesengajaan diberikan teguran atau tindakan administratif serta diproses secara hukum, dan apabila diamati bahwa sanksi yang diberikan adalah sanksi administrasi sebagai perbuatan melanggar kode etik profesi Kepolisian Negara Republik Indonesia, dijelaskan dalam sebagi berikut :

Pasal 34

(1) Sikap dan perilaku pejabat Kepolisian Negara Republik Indonesia terikat pada Kode Etik Profesi Kepolisian Negara Republik Indonesia.

(2) Kode Etik Profesi Kepolisian Negara Republik Indonesia dapat menjadi pedoman bagi pengemban fungsi kepolisian lainnya dalam melaksanakan tugas sesuai dengan peraturan perundangundangan yang berlaku di lingkungannya.

(3) Ketentuan mengenai Kode Etik Profesi Kepolisian Negara Republik Indonesia diatur dengan Keputusan Kapolri.
Pasal 35

(1) Pelanggaran terhadap Kode Etik Profesi Kepolisian Negara Republik Indonesia oleh pejabat Kepolisian Negara Republik Indonesia diselesaikan oleh Komisi Kode Etik Kepolisian Negara Republik Indonesia.

(2) Ketentuan mengenai susunan organisasi dan tata kerja Komisi Kode Etik Kepolisian Negara Republik Indonesia diatur dengan Keputusan Kapolri.

Dari

aspek

pelaksanaannya, hukum mengikat dan adpat dipaksakan oleh alatalat negara, sedangkan kode etik didasarkan pada tuntutan hati nurani, dorongan kekuatan moral dari setiap anggota polisi. Dalam praktik kinerjanya polisi tidak bisa begitu leluasa mengambil tindakan diskresi. Artinya bahawa dalam tugasanya polisi selalu berhadapan dengan kode etik profesinya dan peraturan kedisiplinan.

Etika profesi yang terhimpun dalam kode etik itu sebenarnya merupakan normanorma di dalam kehidupan bersama. Dalam kehidupan bersama itu manusia berpegang pada pasangan nilai-nilai tertentu, yang merupakan pandangan mengenai apa yang dianggap buruk. Etika atau kesusilaan dalam arti luas menunjukkan kepada manusia hal-hal yang 
merupakan suatu yang benar dan mana yang salah. Sebagai salah satu akibat adanya etika, maka muncullah kaidah-kaidah yang cenderung berisikan suruhan, larangan ataupun kebolehan. Bagi ha-hal yang benar tersedia kaidah-kaidah yang berisikan suruhan maupun kebolehan, sedangkan bagi hal-hal yang salah tersedia kaidah-kaidah yang berisikan larangan. Selanjutnya maka kaidah-kaidah tersebut akan mengatur sikap tindak manusia yang mempunyai aspek psiko-sosial dalam arti yang luas". 43

\section{F. Simpulan dan Saran}

\section{Simpulan}

Berdasarkan uraian hasil penelitian dan pembahasan sebagaimana tersebut di atas, maka dapat disimpulkan sebagai berikut :

a. Pelaksanaan diskresi Kepolisian dalam penanganan tindak pidana kecelakaan lalu lintas dengan korban pejalan kaki di daerah hukum Polres Purbalingga, dapat dinyatakan bahwa sebagaian besar kasus Laka Lantas yang melibatkan pejalan kaki (dari 374 kasus laka lantas yang diselesaikan dengan perdamaian 356

43 Soerjono Soekanto, 1995. Efektivitas Hukum dan Peranan Sanksi, Remaja Karya, Jakarta, hlm. 54 kasus) di wilayah hukum

Porles Purbalingga

diselesaikan dengan

pemberian diskresi berupa

cara penyelesaian dengan

perdamaian (musyawarah dan

mufakat) antara pelaku dan

korban atau Restorative

Justice yang merupakan

alternatif penyelesaian

sengketa yang dilakukan di luar pengadilan.

Pelaksanaan diskresi

tersebut didasarkan pada

beberapa pertimbangan,

sebagai berikut :

i. Aspek Sosiologis, apabila dari para pihak sudah menerima/saling

memaafkan sehingga apabila kita memandang dari asas kemanfaatan dan asas keadilan kedua asas tersebut sudah terpenuhi.

ii. Aspek Filosofis, yang dalam hal ini harus tercapai tujuan hukum yaitu terpenuhinya asas kepastian hukum, asas kemanfaatan, dan asas keadilan.

iii. Aspek Yuridis, merupakan aspek yang melandasi aturan hukum yang berlaku, yang dalam hal ini adalah aturan tentang penyelesaian kasus kecelakaan diluar jalur hukum/pengadilan.

b. Diskresi Kepolisian sebagaimana dimaksud Pasal 18 Undang-undang No. 2 Tahun 2002 diperlukan dalam hal untuk mencapai hakikat tujuan penegakan hukum yaitu keadilan dan kemanfaatan, 
1021 | Jurna | I dea Hukum

Vol. 4 No. 2 Oktober 2018

Magister Hukum Fakultas Hukum

Universitas Jenderal Soedirman

sehingga penegakan hukum

pidana dipandang sebagai

ultimum remedium (obat

terakhir), sehingga penyidik

Polri dalam melakukan

penyidikan (termasuk perkara

Laka Lantas) selain

berpedoman kepada aspek

kepastian hukum, penyidik

diharapkan memperhatikan

asas proporsionalitas dengan

memperhatikan aspek-aspek

sebagai berikut :

1) Keadilan yaitu terciptanya rasa keadilan bagi pihakpihak yang terlibat kecelakaan dengan berdasarkan dukungan dari masyarakat.

2) Kemanfaatan yaitu terciptanya keyakinan penyidik dalam penanganan perkara dapat memberikan kemanfaatan bagi pihak-pihak yang terlibat maupun masyarakat umum dalam bentuk keyakinan akan terbentuknya perilaku yang dapat meningkatkan Kamseltibcarlantas.

3) Sosial kemanusiaan yaitu terciptanya hubungan sosial yang baik antara masyarakat dan Polri dengan cara meningkatkan rasa empati penyidik kepada pihak-pihak yang terlibat kecelakaan.

Diskresi

adalah

kewenangan penuh Kepolisian, landasan filosofi diskresi :

a. Sebagai konsekuensi logis dari badan/pejabat Tata Usaha Negara untuk menyenggerakan kesejahteraan umum atas dasar willfare state.

b. Sebagai salah satu alternatif untuk mengatasi kekuraan dan kelemahan dari asas wet materhead van besture.

Syarat diskresi:

a. Undang-undang memberikan pilihan

b. Tidak ada aturan

c. Ada aturan tapi tidak lengkap

d. Untuk menjaga jangan sampai ada stagnasi pemerintahan

\section{Saran}

a. Penyidik kecelakaan lalu-lintas agar dalam melaksanakan diskresi kepolisian dalam penanganan tindak pidana lalu lintas tidak perlu ragu-raga karena sudah terdapat beberapa aturan yang mendasari diskresi, dan diskresi adalah kewenangan penuh dari penyidik kepolisian dengan disetujui oleh Kapolres.

b. Penyidik kecelakaan lalu-lintas harus mampu menerapkan secara matang dalam mendiskresikan suatu perkara kecelakaan lalu-lintas yang perlu untuk didiskresi dengan mempertimbangkan asas keadilan bagi semua pihak, kemanfaatan dan kepastian hokum serta social kemanusiaan. 


\section{DAFTAR PUSTAKA}

Arief, Barda Nawawi 2008. Mediasi Penal Penyelesaian Perkara Di Luar Pengadilan, Pustaka Magister Semarang, Semarang.

Dwilaksana, Chryshnanda, 2011. Kenapa Mereka Takut dan Enggan Berurusan Dengan Polisi? Sebuah Catatan Harian. Yayasan Pengembangan Kajian Ilmu Kepolisian (YPKIK), Jakarta.

Faal, M., 1991. Penyimpangan Perkara Pidana Oleh Polisi, (Diskresi Kepolisian). Pratnya Paramita, Jakarta.

Hadi, Sutrisno, 1999, Metode penelitian hukum. Ghalia Indonesia, Jakarta.

Ibrahim, Jonny, 2008, Teori dan Metodologi Penelitian Hukum Normatif, Bayu Media, Malang.

Morlok, Edward K., 1995. Introduction to Transportation Engenering and Planning, (Pengantar Teknik dan Perencanaan Transportasi), Diterjemahkan oleh Johan Kalanaputra Hainim, Erlangga, Jakarta.

Nurbuko, Cholid, dan H. Abu Achmadi, 2004. Metode Penelitian, Bumi Aksaara, Jakarta.

Rahardi, H. Pudi, 2007. Hukum Kepolisian (Profesionalisme dan Reformasi POLRI). Laksbang Mediatama, Surabaya.
Rahardjo, Satjipto, 1983. Masalah Penegakan Hukum, Sinar Baru, Bandung.

Rahardjo, Satjipto, 1994. Sosiologi Hukum, Makalah Kuliah S2, IImu Hukum,Undip, Semarang.

Sadjijono, 2006. Hukum Kepolisian: Perspektif Kedudukan Kepolisian dan Hubungannya dalam Hukum Administrasi. Laksbang, Yogyakarta.

Setyabudi, Besar, 2004. Kajian Peningkatan Keselamatan Lalu Lintas pada Lokasi Rawan Kecelakaan (Blackspot) di Jalan Tol. Warta Penelitian Perhubungan No. 05/Thn.XVI/2004.

Simorangkir, JCT . dkk, 1980. Kamus Hukum, Aksara Baru, Jakarta.

Soekanto, Soerjono, 1995. Efektivitas Hukum dan Peranan Sanksi, Remaja Karya, Jakarta.

Soekanto, Soerjono, dan Sri Mamudji, 2007. Penelitian Hukum Normatif Suatu Tinjauan Singkat, Raja Grafindo Persada,Jakarta.

Soemitro, Ronny Hanitijo, 1990. Metodelogi Penelitian Hukum dan Jurimetri,Ghalia Indonesia, Jakarta.

Suryabrata, Sumadi, 1992. Metode Penelitian. Rajawali Press, Jakarta.

Susanto, I.S., 1990. Kriminologi. Fakultas Hukum Universitas Diponegoro, Semarang 